1 Morgan HC, Russell GFM. Value of family background and clinical features as predictors of long-term outcome in anorexia nervosa: four year follow-up study of 41 patients. Psychol Med 1975;5:355-71.

2 Marcus R, Kosek J, Pfefferbaum A, Horning S. Age-related loss of trabecular bone in premenopausal women: a biopsy study. Calcif Tissue Int 1983;35:406-9. Garn SM, Kangas J. Protein intake, bone mass and bone loss. In: Deluca HF Fros: HM, Jee WSS, Johnston CC, Parfitt AM, eds. Osteoporosis: recen advances in pathogenesis and treatment. Baltimore: University Park Press,

4 Klibanski A, Neer RM, Beitins IZ, Ridgway EC, Zervas NT, McArthur JW. Decre ased bone density in hyperprolactinemic women. $N$ Engl f Med 1980 ; 303:1511-4.

Saville PD, Nilsson BER. Height and weight in symptomatic postmenopausal osteoporosis. Clin Orthop 1960;45:49-54.

(Accepted 12 October 1984)

Institute of Psychiatry, London SE5 8AF

GEORGE I SZMUKLER, MD, MRCPSYCH, senior lecturer

STEPHEN W BROWN, MRCPSYCH, lecturer

Departments of Renal Medicine and Morbid Anatomy, King's College Hospital, London SE5 8RS

VICTOR PARSONS, DM, FRCP, consultant physician

ALAN DARBY, MRCPATH, senior lecturer

Correspondence and requests for reprints to: Dr George Szmukler.

\section{Suspected myocardial infarction: early diagnostic value of analgesic requirements}

The variety of possible presentations of myocardial infarction is well known, but chest pain is perhaps the most constant of symptoms. Evidence has linked duration of pain with size of infarct, ${ }^{1}$ and Mitchell suggested that analgesic requirements should be used as an early guide to whether infarction has taken place. ${ }^{2}$ I carried out a study to evaluate the diagnostic potential of analgesic requirements.

\section{Patients, methods, and results}

Altogether, 217 consecutive admissions to the coronary care unit were considered for study. Reasons for exclusion ( 97 patients) included rapid death, muscular trauma, and chest pain apparently not due to myocardial ischaemia. Analgesia was given as intravenous diamorphine, usually after a trial of glyceryl trinitrate $0 \cdot 5-1 \cdot 0 \mathrm{mg}$ sublingually.

Infarction was assumed ( 80 patients) if the criteria of Rowley and Hampton for definite or probable myocardial infarction were fulfilled. ${ }^{3}$ The remaining patients were assumed not to have had myocardial infarction, and 40 were included in the study. Infarct size was estimated by plasma creatine kinase activity (highest of four estimations in three days), hydroxybutyrate dehydrogenase activity (highest of three estimations), and the number of electrocardiographic territories (inferior, anterior, lateral, posterior, or equivocal) showing serial changes. Significance was calculated by standard methods with a Texas Instruments TI-99/4A computer.

The group with myocardial infarction had a higher mean (SD) age than the group without $(57.7(10.3) v 52.1(13.3)$ years) and contained a greater proportion of women $(36 \% v 15 \%)$. Men were comparable with women for all variables. The groups were comparable for consumption of $\beta$ blockers and cigarettes. The patients with infarction required larger doses of diamorphine (mean in the first 24 hours $7.07 \mathrm{mg}(103 \mu \mathrm{g} / \mathrm{kg}) v 2.45 \mathrm{mg}(36.7)$ $\mu \mathrm{g} / \mathrm{kg}$ ) and more and later injections (mean number of injections $1.66 v 0.63$; mean time after admission of last injection six hours 48 minutes $v 36$ minutes) (table). The total dose of diamorphine required correlated poorly with variables of infarct size, wide individual variation being evident.

The time after admission of the final injection was the most useful variable only one $(2.5 \%)$ of the group without myocardial infarction required analgesia after two hours compared with half of the group with infarction. Values in patients with equivocal electrocardiographic changes and in the one or two territory groups were $5 \cdot 7,7 \cdot 6$, and $13 \cdot 3$ hours respectively; the correlation with creatine kinase activity was $\mathrm{r}=0.40(\mathrm{p}<0.001)$.

\section{Comment}

The results of this study were consistent with a relation between severity of myocardial infarction and amount of analgesia required in the first hospital day. One fifth of the patients with myocardial infarction, however, did not need any analgesia at all, and one patient without myocardial infarction required $20 \mathrm{mg}$ diam orphine. Moreover, there seems little clinical advantage in attempting to guess the size of myocardial infarction after only 24 hours.
Cumulative incidence of variables of analgesic requirements (figures are numbers $(\%)$ of patients)

\begin{tabular}{|c|c|c|}
\hline & $\begin{array}{c}\text { Myocardial } \\
\text { infarction } \\
(\mathbf{n}=80)\end{array}$ & $\begin{array}{c}\text { Non- } \\
\text { infarction } \\
(n=40)\end{array}$ \\
\hline $\begin{array}{l}\text { No of injections in first } 24 \text { hours: } \\
\text { None } \\
\text { One or none } \\
\text { Two or fewer }\end{array}$ & $\begin{array}{l}16(20 \cdot 0) \\
39(48 \cdot 8) \\
63(78 \cdot 8)\end{array}$ & $\begin{array}{l}22(55 \cdot 0) \\
35(87.5) \\
39(97.5)\end{array}$ \\
\hline $\begin{array}{l}\text { Dose of diamorphine }(\mu \mathrm{g} / \mathrm{kg}) \text { in first } 24 \text { hours: } \\
\text { Up to } 27.5 \\
\text { Up to } 30.0 \\
\text { Up to } 40.0\end{array}$ & $\begin{array}{l}46(57 \cdot 5) \\
51(63 \cdot 8) \\
68(85 \cdot 0)\end{array}$ & $\begin{array}{l}35(87.5) \\
36(90.0) \\
39(97.5)\end{array}$ \\
\hline $\begin{array}{l}\text { Time after admission (hours) of final injection: } \\
\text { Up to } 1 \\
\text { Up to } 2 \\
\text { Up to } 3 \\
\text { Up to } 8 \\
\text { Up to } 12 \\
\text { Up to } 18\end{array}$ & $\begin{array}{l}39(48 \cdot 8) \\
40(50) \\
40(50) \\
53(66 \cdot 3) \\
61(76 \cdot 3) \\
68(85)\end{array}$ & $\begin{array}{l}38(95.0) \\
39(97.5) \\
39(97.5) \\
39(97.5) \\
39(97.5) \\
39(97.5)\end{array}$ \\
\hline
\end{tabular}

In the early decision of whether infarction has taken place analgesic requirements may be of greater value. This study suggests that if a second injection of analgesia is required in the first 24 hours the chances of myocardial infarction being excluded lengthen to one in eight and myocardial infarction is four times more likely. If three or more injections are needed myocardial infarction is 10 times more likely. If a second injection is required more than three hours after admission exclusion of myocardial infarction becomes a 40 to one chance and infarction is 20 times more likely. Thus if this three hour rule was applied it would indicate infarction with a specificity of $97.5 \%$ and a similar predictive value. A negative result is less reliable, the sensitivity being $50 \%$.

These results confirm that analgesic requirement can be related to the size of myocardial infarction, but the clinical value of this is doubtful. Analgesic requirement can also be used as an early guide to the presence or absence of myocardial infarction. The duration of symptoms seems to be the most important factor, and if further analgesia is required after three hours in hospital this is highly suggestive of infarction.

1 Ledwich JR, Mondragon GA. Chest pain duration in myocardial infarction. fAMA 1980:244:2172-4.

Mitchell JRA. "But will it help my patients with myocardial infarction ?" The implications of recent trials for everyday country folk. BrMedf 1982;284:1140-8. Med $1981 ; 26: 253-8$.

(Accepted 10 October 1984)

Coronary Care Unit, Royal Liverpool Hospital, Liverpool L7 8XP PAUL BAKER, MB, MRCP, senior house officer

Correspondence to: Collegiate Medical Centre, Brideoak Street, Cheetham, $M$ inchester M8 7AX.

\section{Audit of control of heparin treatment}

A recent study of warfarin treatment showed poor control of anticoagulation. ${ }^{1}$ We performed an audit of heparin treatment. The kaolin cephalin clotting time is the method of choice for measuring the effect of heparin in the United Kingdom. It is simple and convenient, standardised nationally, and effective. ${ }^{2}$ The optimum therapeutic range is $1.5-2.5$ times the control value, which seems to be little known among junior staff. Above this range there is a greater risk of haemorrhage, and below it treatment is likely to be suboptimal. ${ }^{2}$

\section{Patients, methods, and results}

Data were collected prospectively on 45 consecutive patients (23 men, 22 women; mean age 55 (range 24-80)) and 180 heparin days analysed. Patients received heparin via an electric infusion pump $(n=30)$ or a paediatric burette operated by a nurse $(n=15)$. Responses of doctors to kaolin cephalin clotting times outside the therapeutic range, as reflected by changes they made in the rate of infusion of heparin, were analysed. For 28 patients we constructed a dose response curve and calculated the infusion rate required to achieve a kaolin cephalin clotting time of 60 seconds ( 1.5 times control in our laboratory).

The kaolin cephalin clotting time was within the therapeutic range on 
45 days, above it on 51 , and below it on 84 . Patients received heparin for a median of four days, and the kaolin cephalin clotting time was within the therapeutic range for a median of one day in each patient (though never in 13 patients) (table). Interestingly, there was no trend towards improved control with duration of treatment.

Day by day analysis of anticoagulant state of patients receiving heparin infusion (figures are numbers $(\%)$ of patients)

\begin{tabular}{lcccccc}
\hline & $\begin{array}{c}\text { Day 1 } \\
(\mathrm{n}=45)\end{array}$ & $\begin{array}{c}\text { Day 2 } \\
(\mathrm{n}=45)\end{array}$ & $\begin{array}{c}\text { Day 3 } \\
(\mathrm{n}=41)\end{array}$ & $\begin{array}{c}\text { Day 4 } \\
(\mathrm{n}=36)\end{array}$ & $\begin{array}{c}\text { Day 5 } \\
(\mathrm{n}=12)\end{array}$ & $\begin{array}{c}\text { Day 6 } \\
(\mathrm{n}=1)\end{array}$ \\
\hline $\begin{array}{l}\text { Within therapeutic range } \\
\text { Above therapeutic range }\end{array}$ & $10(22)$ & $10(22)$ & $14(34)$ & $7(20)$ & $4(33)$ & \\
Below therapeutic range & $23(51)$ & $27(60)$ & $12(29)$ & $17(47)$ & $5(42)$ & $1(100)$ \\
\hline
\end{tabular}

Doctors ignored $26 \%$ of all the measurements of kaolin cephalin clotting time that required a change in heparin infusion rate and changed the infusion rate in the wrong direction in $12 \%$. Although in the right direction, $85 \%$ of the remaining changes failed to achieve a therapeutic kaolin cephalin clotting time. The therapeutic range was achieved on $27 \%$ of the days by infusion pump and on $19 \%$ of the days by burette $(p>0.05)$. The mean (SD) infusion rate required to achieve a therapeutic kaolin cephalin clotting time of 60 seconds was $1404(432) \mathrm{U} / \mathrm{h}(\mathrm{n}=28$, range $690-2500 \mathrm{U} / \mathrm{h})(1513$ (417) $U / h$ in men and $1278(429) U / h$ in women $(p>0.05)$ ). There was no significant relation between the therapeutic infusion rate and the age or weight of the patient.

\section{Comment}

Heparin control in our hospital is poor, with $26 \%$ of kaolin cephalin clotting times being ignored, $12 \%$ of responses being made in the wrong direction, and a high degree of inaccuracy in remaining responses. Accurate control is complicated by two other factors: firstly, there is wide interpatient variation in drug clearance and responses of the kaolin cephalin clotting time to given plasma heparin concentrations ${ }^{3}$; and, secondly, the response to heparin is not linear, so that a given increment in the heparin infusion rate will not result in a proportionate increment in the kaolin cephalin clotting time. ${ }^{4}$

Heparin should be delivered by infusion as this avoids potentially dangerous peaks of heparin activity (and correspondingly greater risk of haemorrhage) that sometimes occur after bolus injections. ${ }^{5}$ Although we expected infusion pumps to maintain a steadier rate of infusion than burettes operated by nurses, the difference in control was not significant, and so other factors must also affect control.

If the concept of a therapeutic range of kaolin cephalin clotting time is accepted more attention should be paid to it when controlling treatment with heparin, a potentially dangerous drug. As the kaolin cephalin clotting time approaches the therapeutic range lower increments in the heparin infusion rate should be made to achieve equivalent increments in the kaolin cephalin clotting time. Individual titration of the infusion rate is necessary to optimise efficiency and reduce potential toxicity. Long and short kaolin cephalin clotting times should not be ignored.

We thank the consultant staff of Llandough Hospital for allowing us to use their patients for this study.

1 Duxbury B. Therapeutic control of anticoagulant treatment. Br Med f 1982;284

2 Basu D, Gallus A, Hirsh J, Code J. A prospective study of the value of monitoring heparin treatment with the activated partial thromboplastin time. N Englf Med 1972;287:324-7.

3 Hirsh J, Van Aken W, Gallus A, Dollery C, Code J, Yung W. Heparin kinetics in venous thrombosis and pulmonary embolism. Circulation 1976;53:691-5.

4 Bjornsson TD, Woolfram KM. Determinants of the anticoagulant effect of heparin in vitro. Ann NY. Acad Sci $1981 ; 370: 656-61$.

abrion E, Degkin D, Shapiro R, Rosenburg R. Management of heparin therapy.

Accepted 8 October 1984)

Llandough Hospital, Penarth, South Glamorgan CF6 1XX

A G FENNERTY, MB, MRCP, research fellow

$P$ THOMAS, MB, MRCP, registrar

G BACKHOUSE, FIMLS, technician

P BENTLEY, MRCP, MRCPATH, consultant haematologist

I A CAMPBELL, MD, FRCPED, consultant physician

Department of Pharmacology and Therapeutics, University of Wales College of Medicine

P A ROUTLEDGE, MD, MRCP, senior lecturer in clinical pharmacology

Correspondence to: Dr A G Fennerty.

\section{Why do people seek treatment by alternative medicine?}

Interest in complementary medicine is clearly increasing, ${ }^{12}$ but no one has asked the general public why they seek such treatment. We carried out a study at the Centre for Alternative Therapies to evaluate the characteristics of patients seeking treatment. The scope of their presenting problems, the reasons why patients elect to be treated by complementary medicine, patients' knowledge, attitudes, and expectations about such treatment, and the efficacy of these methods in pain and depression were assessed. The centre is private, although $20 \%$ of patients are classed as socially disadvantaged and are seen either free of charge or for a small fee. The services offered include acupuncture, manipulative medicine, homoeopathy, clinical ecology, biofeedback, psychotherapy, the Alexander technique, and hypnosis.

\section{Patients, methods, and results}

We compiled a questionnaire to evaluate our aims after several open recorded interviews with patients. The questionnaire was given to all 65 new patients seen at the centre over four weeks. Twenty minute interviews took place after the patients had seen one of the doctors. Eight weeks after the first interview a follow up questionnaire was issued, and strenuous efforts were made to ensure maximum response.

Fifty six of the 65 patients completed the follow up questionnaires. The largest group of patients attending the centre were in social class II, married, female, and aged 26-50. Patients came with many chronic problems; pain accounted for $45 \%$ of the presenting complaints (table). Duration of symptoms varied from three months to 44 years (mean nine years). Most patients had seen both their general practitioner and a specialist; only three had bypassed conventional medicine. One third of the patients had consulted the doctor at the centre on the recommendation of friends, although general practitioners were responsible for $22 \%$ of referrals.

Presenting problems of patients

\begin{tabular}{|c|c|c|}
\hline Complaint & No of patients & Specification of complaint \\
\hline Pain & 30 & $\begin{array}{l}\text { Arthritis, back pain, abdominal pain, } \\
\text { headaches }\end{array}$ \\
\hline $\begin{array}{l}\text { Allergies } \\
\text { Non-specific symptoms } \\
\text { Psychological } \\
\text { Gynaecological } \\
\text { Gastrointestinal }\end{array}$ & $\begin{array}{r}10 \\
9 \\
3 \\
2 \\
3\end{array}$ & $\begin{array}{l}\text { Eczema, urticaria, asthma, rhinitis } \\
\text { Malaise, feeling unwell, run down } \\
\text { Anxiety, smoking } \\
\text { Dysmenorrhoea, candidiasis } \\
\text { Coeliac disease, spastic colon, diarrhoea, }\end{array}$ \\
\hline $\begin{array}{l}\text { Hypertension } \\
\text { Loss of balance } \\
\text { Others }\end{array}$ & $\begin{array}{l}2 \\
2 \\
6\end{array}$ & $\begin{array}{l}\text { Loss of voice, catarrhal deafness, } \\
\text { Raynaud's disease, acne, muscle } \\
\text { wasting, facial rash }\end{array}$ \\
\hline
\end{tabular}

Fifty four patients stated that failure of conventional medicine was their reason for attending. Most of these people had a good relationship with their general practitioner and thought that they had received satisfactory treatment from conventional doctors. Nineteen patients thought that they were rushed by their general practitioners, but 18 also claimed to be rushed by the doctor at the centre. About half the patients (31) thought that their general practitioner did not understand their problems; conversely, 53 thought that the doctor at the centre had a good understanding of their difficulties. Most of the patients said that they would return to conventional medicine for future problems.

The patients appeared to be well informed about alternative medicine, the main source of information being friends and the media. Attending the centre did not increase this knowledge. Two thirds of the patients believed that alternative methods worked, and many had high expectations of treatment. Expectations appeared to be correlated with outcome: if people expected to get better treatment was more likely to be effective. After eight weeks 33 patients felt much better, although only 19 had completed their treatment at this time. This subjective improvement was reflected in a decrease in the mean depression scores as measured by the Wakefield scale $(\mathrm{F}=4.996, \mathrm{p}<0.05)^{3}$ and a decrease in pain as measured by visual ana!ogue scales $(t=3 \cdot 3, \mathrm{p}<0.01)$.

\section{Comment}

Patients seen at the centre were not "cranks" and had not lost confidence in conventional medicine. They were well informed and seeking a solution to unresolved long term problems. Our study showed that $59 \%$ of patients attending the centre felt much better after eight weeks' treatment. Further studies should be directed at exploring the reasons for the increase in provision of alternative 